\title{
Prevalence and genotyping of Toxoplasma gondii in stray cats in Mashhad area, Iran
}

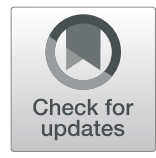

Majid Khodaverdi and Gholamreza Razmi* (B)

\begin{abstract}
Background: Cats as a definitive host have an important role in the epidemiology of toxoplasmosis in humans and animals. The aim of the study was to determine the frequency of Toxoplasma gondii infection and isolate and identify the genotypes of T. gondii in stray cats in the Mashhad suburb.

Methods: From April 2016 to August 2017, 175 fecal samples from stray cats and 31 brain samples from cats killed in driving accidents were collected. The fecal samples were examined by fecal flotation technique and T. gondiispecific PCR. The brain samples were investigated by T. gondii-specific PCR and consequently examined by mice bioassay. The DNA of T. gondii isolated was genotyped using SAG1, SAG2, SAG3, BTUB and GRA6 as PCR-restriction fragment length polymorphism (PCR-RFLP) markers.

Results: In the present study, Toxoplasma-like oocysts were microscopically observed in 2.2\% (4/175) fecal samples. The presence of Toxoplasma oocysts was confirmed in one microscopy-positive sample by PCR. In addition, T. gondii DNA was detected in 4\% (7/175) microscopy-negative samples using PCR. T. gondii was isolated from one brain PCR-positive sample by mice bioassay. The isolate was avirulent and many $T$. gondii cysts were observed in mice brain. The isolate was successfully genotyped by PCR-RLFP analysis. The isolated genotyped was type II. Besides, eight Toxoplasma-positive fecal samples contained insufficient DNA and only amplified at SAG-3 locus in PCR. These samples were also showed type II pattern at this locus.
\end{abstract}

Conclusions: Parasitological and molecular results showed low frequency of Toxoplasma infection in the stray cats, and identified the genotype of T. gondii isolate as type II, for the first time in Mashhad area, Khorasan Razavi Province.

Keywords: Toxoplasma gondii, Cats, Genotype, Mice bioassay, PCR-RLFP

\section{Background}

Toxoplasmosis is considered an important zoonotic disease caused by $T$. gondii, an obligate intracellular protozoan [1]. Sexual stage develops only in cat and other felids as the definitive hosts that excrete heavy walled oocysts in feces. It typically occurs in humans and other warmblooded animals as intermediated hosts tachyzoites are formed first, followed by the formation of tissue cysts. $T$. gondii infection is also transmitted by different routes in humans and animals. Humans acquire Toxoplasma infection by eating undercooked or raw meat containing viable tissue cysts, or by direct ingesting of sporulated oocysts and or by congenital route $[1,2]$.

\footnotetext{
* Correspondence: razmi@um.ac.ir

Department of Pathobiology, Faculty of Veterinary Medicine, Ferdowsi

University of Mashhad, P.O. Box: 91775-1793, Mashhad, Iran
}

A large proportion of T. gondii infection is asymptomatic in humans, but may lead to acute and fatal toxoplasmosis in immunocompromised patients [3]. Congenital toxoplasmosis can cause abortion, stillbirths or fetal death [4]. The severity of toxoplasmosis is associated with genetics and immunity of host and Toxoplasma strains [1].

Based on the virulence levels of Toxoplasma strains in outbred mice, strains were classified into three genotypes: I, II and III [5]. Multilocus PCR-restriction fragment length polymorphism (PCR-RFLP), microsatellite DNA analysis and multilocus DNA sequence typing of intron methods have been used to determine the T. gondii genotype in many studies [6,7]. More genotyping studies used multilocus PCR-RLFP analysis of five to ten markers. Among these markers, SAG1, SAG2, SAG3, BTUB, GRA6 could clearly differentiate different genotypes by using

(c) The Author(s). 2019 Open Access This article is distributed under the terms of the Creative Commons Attribution 4.0 International License (http://creativecommons.org/licenses/by/4.0/), which permits unrestricted use, distribution, and 
nested PCR reactions followed by endonuclease digestion [8-11]. So far, many Toxoplasma types were identified that were genetically different with classical types and some have been categorized under unclonal genotypes $[9,12]$. An infected cat as the definitive host may shed 1 billion oocysts during primary infection and have the main role in the epidemiology of toxoplasmosis [1] .Many seroepidemiological studies have been performed on $T$. gondii infection in humans and animals in Iran [13]. The overall seroprevalence of Toxoplasma infection was estimated to be $22-86 \%$ in cats [13]. Despite a high seroprevalence of $T$. gondii in cats in Iran, there are few studies on genetic characterization of $\mathrm{T}$. gondii isolates in cats. The present study was designed to determine the occurrence of T. gondii in cat feces and to isolate and identify $T$. gondii genotype by using mouse bioassay and PCR-RFLP.

\section{Results}

A total of 175 fecal samples, low number Toxoplasmalike oocysts with a diameter 9-12 $\mu \mathrm{m}$, were microscopically observed in $2.2 \%(4 / 175)$ of fecal samples, whereas, T. gondii DNA was detected in 4/5\% (8/175) of fecal samples by nested-PCR. One infected fecal sample with Toxoplasma-like oocysts was positive only by nestedPCR. No significant statistical differences were identified between the prevalence of $T$. gondii infection in different age and gender groups of stray cats (Table 1) $(p>0.05)$. The DNA of $T$. gondii was detected in $3.2 \%(1 / 31)$ of the brain samples and $6.8 \%(2 / 31)$ fecal samples of dead cats by PCR. All brain samples were examined by mice bioassay, T. gondii was isolated only from the PCR-positive brain sample. Poor agreement was observed between parasitological and PCR methods (Kappa $=0.0 .127$ ).

Many $T$. gondii tissue cysts were microscopically observed at $6 \mathrm{wk}$. PI in the brain smears of inoculated mice. The size of cysts range was $7-22 \mu \mathrm{m}$. The course of infection was without symptoms in all infected mice,

Table 1 Results of fecal flotation technique and PCR examination of feces of stray cats in Mashhad area

\begin{tabular}{|c|c|c|c|c|c|}
\hline \multirow[t]{2}{*}{ Variable } & \multicolumn{2}{|c|}{ Fecal flotation technique } & \multicolumn{2}{|c|}{ PCR of Feces } & \multirow[t]{2}{*}{ Total } \\
\hline & $\begin{array}{l}\text { Negative } \\
\text { No }\end{array}$ & $\begin{array}{l}\text { Positive } \\
\text { No (\%) }\end{array}$ & $\begin{array}{l}\text { Negative } \\
\text { No }\end{array}$ & $\begin{array}{l}\text { Positive } \\
\text { No (\%) }\end{array}$ & \\
\hline \multicolumn{6}{|l|}{ Gender } \\
\hline Male & 58 & $3(4.9)$ & 58 & $3(4.9)$ & 61 \\
\hline Female & 113 & $1(0.9)$ & 109 & $5(4.8)$ & 114 \\
\hline \multicolumn{6}{|l|}{ Age (year) } \\
\hline$<1$ & 32 & $1(3)$ & 32 & $1(3)$ & 33 \\
\hline $1-3$ & 53 & $1(1.8)$ & 53 & $1(1.5)$ & 54 \\
\hline$>3$ & 86 & $2(2.2)$ & 82 & $6(6.8)$ & 88 \\
\hline Total & 171 & $4(2.2)^{a}$ & 167 & $8(4.5)^{a}$ & 175 \\
\hline
\end{tabular}

anly one sample was positive both parasitology and PCR thus indicating the isolation of an avirulent (murine) strain. The five multilocus PCR-RFLP analyses revealed that the isolate of brain mice gave restriction digest patterns consistent with infection with type II. Eight Toxoplasma-positive fecal samples were also genotyped using PCR-RLFP analysis. These samples contained insufficient DNA Toxoplasma genotyping and only amplified at SAG-3 locus in PCR. The type II pattern was also observed at this marker. The amplified B1 genes of the Toxoplasma isolate was sequenced and deposited in GenBank (NCBI) under accession no of MH673033.

\section{Discussion}

In the current study, $T$. gondii-like oocysts were microscopically detected in $2.2 \%(4 / 175)$ of fecal samples. The presence of Toxoplasma oocysts was confirmed in one microscopy-positive sample by PCR. Other samples may be infected with other $T$. gondii-like oocysts such as Hammondia spp. In the present study, no T. gondii-like oocysts were detected in $4 \%(7 / 175)$ of PCR positive samples. This result may be due to consumption of meat contaminated with Toxoplasma cysts or due to the small number of Toxoplasma oocysts in fecal specimens which are difficult to determine by fecal examination. Similar to our results, a low prevalence of oocysts shedding in cats was determined at $1.2 \%$ in Iran [14], at $2.3 \%$ in Italy [15], at $0.3 \%$ in Japan [16], at $0.14 \%$ in Germany [17], at $0.4 \%$ in Switzerland [18], at $4.7 \%$ in South Korea [19], at 0.9 in the USA [20], at $0.8 \%$ in Thailand [21], at $0.76 \%$ in Finland [22] by microscopy and PCR methods. In contrast to serological studies, examining feces did not show any information about age and gender as risk factors, due to the low prevalence of oocyst shedding by the cats $[13,23]$.

Toxoplasma gondii was isolated from the brain of a PCR-positive stray cat by mice bioassay. All inoculated mice survived and developed antibodies against $T$. gondii until sacrifice time, thus indicating the isolate belongs to avirulent strain $[5,24,25]$. In the previous study, a nonvirulent strain was isolated from aborted ovine fetuses in Mashhad, Iran, by bioassay method [26].

The PCR-RFLP assay at five markers revealed that the avirulent isolate in this study belongs to type II clonal lineage. These five markers have been successfully used in T. gondii genotypes in cats in previous studies and proved to identify the genotype of isolates in cats [27-29]. Although, ten genetic markers allow isolates with high resolution [30]. In Iran, types II and III isolates have been detected by RLFP analysis at GRA6 locus [31, 32] and type I and III by RLFP analysis at SAG 2 locus in stray cats [33]. In addition, type II has been detected in humans, sheep and birds by PCR- RLFP assay at GRA6 and in wild rats by SAG 1 locus [34, 35]. However, a single marker was used to genotype Toxoplasma in these studies but it 
does not allow identification of nonclonal strains, and to determine more precisely the presence of polymorphisms in the population [7, 36]. Our result also agreed with similar studies in other countries that type II was detected in stray cats using PCR-RLFP [20, 23, 29, 37-41]. In Europe and North America, type II is the most prevalent strain isolated from both humans and animals [6, 42].

\section{Conclusions}

Based on our results, the presence of $T$. gondii oocysts was identified in one fecal sample of stray cats. In addition, $T$. gondii type II genotype was identified for the first time in stray cats in Mashhad area. Further, similar studies with more markers are required to provide wider insight about the different Toxoplasma strains in cats in different parts of Iran.

\section{Methods}

\section{Research location}

The study was performed in Mashhad area as the center city of Khorasan Razavi province from April 2016 to August 2017. The city is located at $36.20^{\circ}$ North latitude and $59.35^{\circ}$ East longitude, in the valley of the Kashafrud River near Turkmenistan, between the two mountain ranges of Binalood and Hezar Masjed Mountains. The city benefits from the proximity of the mountains, having cold winters, pleasant springs, and mild summers (Fig. 1).

\section{Sampling}

One hundred seventy- five stray cats were trapped from different areas of the Mashhad in with the help of local municipality. Furthermore, Thirty-one samples were from killed stray cats during driving accidents. The trapped cats and carcasses were transferred to the diagnostic laboratory

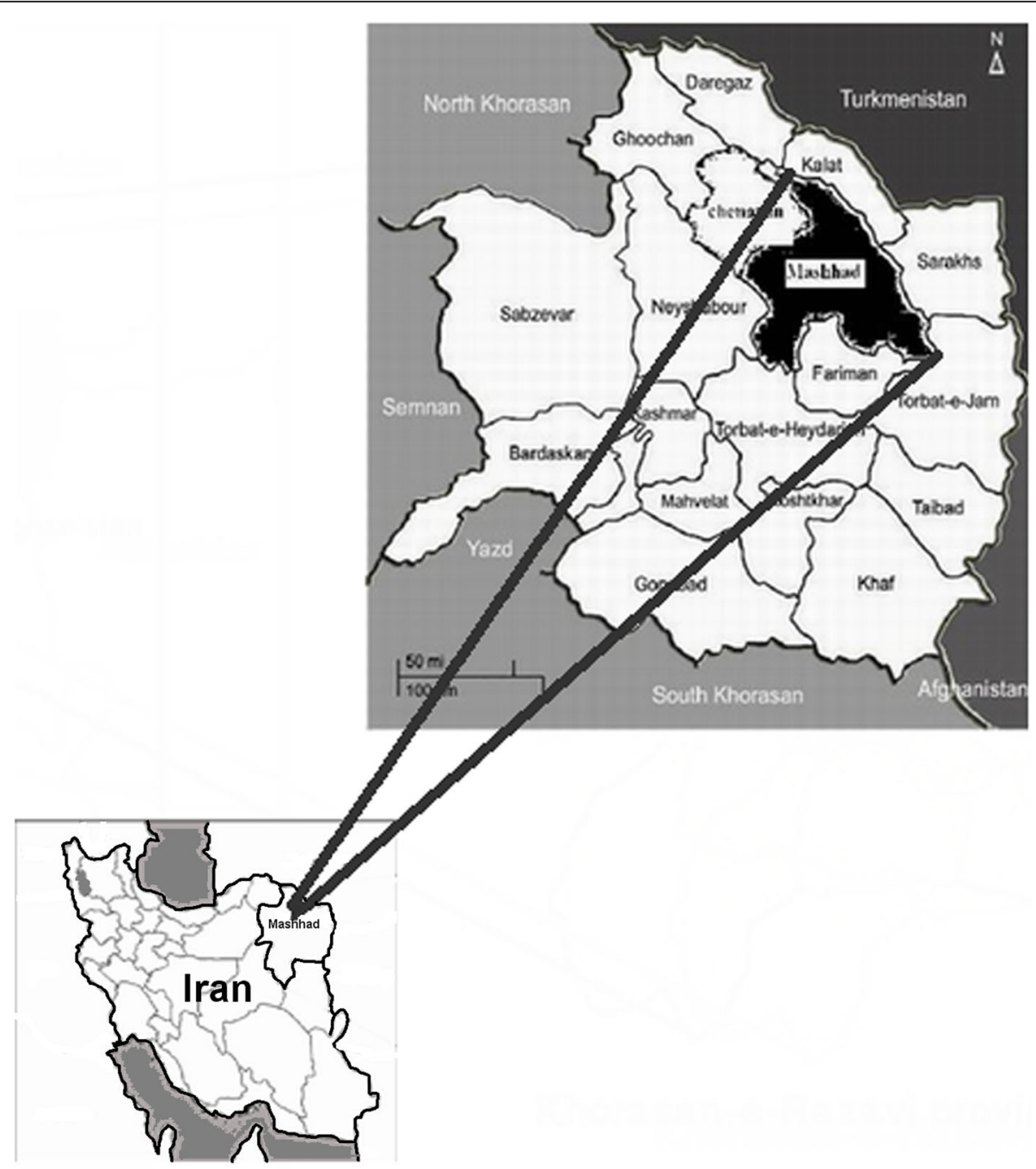

Fig. 1 The map of sampling location in Khorasan Razavi province, Iran. The sources of the map of Khorasan province was from the our previous study at http://ijpa.tums.ac.ir/index.php/ijpa/article/view/284 and the map of Iran at http://en.wikipedia.org/wiki/File:Locator_map_Iran_Razavi_Khorasan 
of the parasitology department for laboratory examination. They were sedated by premedication with intramuscular (IM) Ketamine hydrochloride $(6 \mathrm{mg} / \mathrm{kg})$. The approximate age of the cat was determined by teeth examination. All of the adult teeth are in place by 6 months of age, and the growth is no longer useful in determining a cat's age. In older cats, the amount of staining, or tartar, on a cat's teeth is also an indicator of age. Then, the data related to their age, the sex were recorded and collected feces from each cat. The killed cats were necropsied and feces and the brain were collected. Collected fecal and brain samples were kept in a refrigerator at $4{ }^{\circ} \mathrm{C}$ for further examination. The trapped cats were released after sampling with the help of the Mashhad municipality.

\section{Parasitological method}

Feces $(1 \mathrm{~g})$ of each animal were emulsified in sucrose solution (specific gravity 1.203), filtered through gauze, and centrifuged in a $15 \mathrm{~mL}$ tube at $400 \mathrm{~g}$ for $10 \mathrm{~min}$. A drop of the float from the meniscus was examined microscopically at $\times 400$ magnifications for the presence of $T$. gondii oocysts [1]. The size of oocysts was measured by a calibrated ocular micrometer (Zeiss Company, Germany).

\section{Nested-PCR amplification}

Oocysts of fecal samples were repeatedly washed in PBS and homogenized by grinding with $0.5 \mathrm{~mm}$ glass beads for $30 \mathrm{~min}$. DNA of homogenized oocysts, fecal and brain samples were extracted by a commercial kit (Molecular and Biological Transmission Systems (MBST), Tehran, Iran) as per manufacturer's recommendations. T. gondii B1 gene PCR amplification was carried out using a nested-PCR, as previously described by Burg et al. [43]. Amplification in $25 \mu \mathrm{L}$ reaction volumes (Accupower PCR premix kit, Bioneer ${ }^{\oplus}$, South Korea) in the first reaction contained: $250 \mu \mathrm{M}$ of each dNTP, $10 \mathrm{mM}$ Tris- $\mathrm{HCl} \mathrm{pH}$ 9.0, $30 \mathrm{mM} \mathrm{KCl}$ and $2 \mathrm{mM} \mathrm{MgCl} 2,1 \mathrm{U}$ Taq DNA polymerase and $10 \mathrm{pmol}$ of each PCR primer (Denazist, Mashhad, Iran). Then $1 \mu \mathrm{L}$ of DNA template (250-500 ng) was added to each reaction and the remaining $25 \mu \mathrm{L}$ reaction volume was filled with sterile distilled water.

After 3 min of initial denaturation at $94^{\circ} \mathrm{C}, 38$ cycles of amplification (each cycle: $1 \mathrm{~min}$ at $94^{\circ} \mathrm{C}, 1 \mathrm{~min}$ at $50{ }^{\circ} \mathrm{C}$, and $1 \mathrm{~min}$ at $72^{\circ} \mathrm{C}$ ) and a final extension step for $7 \mathrm{~min}$ at $72{ }^{\circ} \mathrm{C}$ were performed in an automated thermocycler (MJ Mini Thermal Cycler, Bio-Rad Co, USA). The PCR products were visualized by electrophoresis on a $1.5 \%$ agarose gel. One $\mu \mathrm{L}$ of the diluted $(1,10)$ each reaction is then used in the second reaction in the same mixture and cycling condition, except for the annealing temperature, which was $52{ }^{\circ} \mathrm{C}$; the number of cycles was 30 . The presence of specific bands of $193 \mathrm{bp}$ in primary PCR and $96 \mathrm{bp}$ in nested -PCR on agarose gel was considered a positive sample [43]. Distilled water were used as a negative control and $T$. gondii strains (RH) was used as positive controls.

\section{Isolation of T.gondii}

The tissue homogenates were prepared from the brain tissue of the cats as the method described by Dubey [1]. Briefly, $100 \mathrm{~g}$ of brain samples were homogenized in 0.5 $\mathrm{L}$ of normal saline $(0.85 \%)$ with penicillin $100 \mathrm{IU} / \mathrm{mL}$ and streptomycin $1 \mathrm{mg} / \mathrm{mL}$ by the electrical mixture. The tissue homogenate was strained through 2 layers of gauze to remove coarse material. The homogenate was kept at room temperature for 3 hours and centrifuged at $1.500 \mathrm{~g}$ for $5 \mathrm{~min}$. The homogenate $(0.5 \mathrm{~mL}$ per each mouse) inoculated subcutaneously to Swiss Webster mice (Razi Vaccine\& serum research institute, Mashhad, Iran). None inoculated mice were shown clinical signs. Six weeks after inoculation, blood samples were collected from the tail of mice. Serum samples were separated and analyzed for the presence of antibodies against T. gondii by ELISA test (ID.vet Innovative Diagnostics, Grabels, France). Seropositive mice were killed at 42 days post-infection by chloroform-inhalation. Then, the mouse brain was homogenized with an equal volume of sterile normal saline by passing through a $16 \mathrm{~g}$ needle ten times by mean a syringe. One drop of given suspension placed on a slide and spread out covered with a slip and microscopically examined. At least five slides should be examined. The isolation of T.gondii was successful if Toxoplasma cysts were found in the mouse brain.

\section{PCR-RFLP analysis}

PCR-RFLP with SAG1, SAG2, SAG3, BTUB and GRA6 markers were performed to determine the $T$. gondii genotype in fecal and brain samples according to described methods [8-11]. Briefly, the PCR reaction was performed in a $25 \mu \mathrm{l}$ reaction mixture containing $1 \mu \mathrm{l}$ of extracted DNA, $75 \mathrm{mM}$ Tris- $\mathrm{HCl} \quad(\mathrm{pH} 8.5), 20 \mathrm{mM}$ (NH4)2SO4, $1.5 \mathrm{mM} \mathrm{MgCl2,0.1 \%} \mathrm{Tween} \mathrm{20,} 0.2 \mathrm{mM}$ dNTPs, $0.025 \mathrm{U} / \mu \mathrm{l}$ amplicon Taq DNA polymerase, inert red dye, a stabilizer and $10 \mathrm{pmol}$ of each primer described in Table 1 After $5 \mathrm{~min}$ of initial denaturation at $95^{\circ} \mathrm{C}, 35$ cycles of amplification followed by $30 \mathrm{~s}$ at $94{ }^{\circ} \mathrm{C}, 1 \mathrm{~min}$ at $60^{\circ} \mathrm{C}, 2 \mathrm{~min}$ at $72^{\circ} \mathrm{C}$, and a final extension of $72{ }^{\circ} \mathrm{C}$ for $10 \mathrm{~min}$ (MJ Mini Thermal Cycler, BioRad Co, USA).

After that, $1.5 \mathrm{U}$ of enzymes endonuclease with $2 \mathrm{U}$ buffers was added to $15-\mathrm{mL}$ of each PCR product and incubated as the manufacturer's protocol. The digested products were electrophoresed to separate restriction fragments in $1.6 \%$ agarose gel. Finally, the agarose gel was stained with ethidium bromide and visualized under UV. The extracted DNA of the RH strain was used as a positive control. 


\section{DNA sequencing}

The purified PCR products of B1 with primers were sent to DNA sequencing in the Bioneer Inc. (Bioneer Company, Seoul, and Company). The assembling and editing of nucleotide sequences were used by CLc bio software.

\section{Statistical analysis}

The chi-square test analyzed the relationship between infection rate and variables such as age and gender. A significant association was identified when a $p$-value of less than 0.05 was observed [44]. The agreement between the different tests was showed as a k-value. The agreement as poor if $\mathrm{k}$-values between 0.2 and 0.4 , moderate if $\mathrm{k}$-values between 0.4 and 0.6 , substantial if 0.6 and 0.8 and good if it exceeds 0.8 and 1.3 [44].

\begin{abstract}
Abbreviations
BTUB: Beta-tubulin; ELISA: Enzyme-linked immunosorbent assay; GRA6: Dense granule protein-6; NCBI: National Center for Biotechnology Information; PCR: Polymerase chain reaction; PCR-RFLP: PCR-restriction fragment length polymorphism; SAG-1-3: Surface antigen-1-3
\end{abstract}

\section{Acknowledgments}

We thank the municipality of Mashhad for cooperation and assistance in collecting stray cats. We would like to thank Mr. Amin Bakhshani for his help during sampling. We thank Dr. Hasan Borji our colleague in the Faculty of Veterinary Medicine for permission to use Khorasan Razavi Province map in the graphical design of Fig. 1.

\section{Authors' contributions}

GR was the supervisor of project and analyzed the data and was a major contributor in writing the manuscript. MK collected samples, performed the experiments and helped to draft the manuscript. All authors read and approved the final manuscript.

\section{Funding}

This study was based on a Ph.D. thesis for the Veterinary Parasitology that funded by a grant (No.3.40334) from the Research council of the Ferdowsi University of Mashhad. The funders had no role in study design, data collection, analysis, the decision to publish or the preparation of the manuscript.

\section{Availability of data and materials}

The datasets used and/or analyzed (Persian language) during the current study are available from the corresponding author on reasonable request.

\section{Ethics approval and consent to participate}

The experiment on animals in the present study was approved by Ethics Committee of Ferdowsi University of Mashhad (Approval ID: IR.UM.REC.1398.083). Sampling of stray cats was carried out with the permission and cooperation of the Mashhad Municipality and the Veterinary Organization of Khorasan Razavi Province.

\section{Consent for publication}

Not applicable.

\section{Competing interests}

The authors declare that they have no competing interests.

Received: 25 August 2019 Accepted: 12 November 2019 Published online: 21 December 2019

\section{References}

1. Dubey JP. Toxoplasmosis of animals and humans. 2nd ed. Boca Raton: CRC Press; 2010.

2. Tenter IS, Heckeroth AR, Weiss LM. Toxoplasma gondii: from animals to humans. Inter J Parasitol. 2010;30:1217-58.
3. Cuomo G, D'Abrosca V, Rizzo V, et al. Severe polymyositis due to Toxoplasma gondii in an adult immunocompetent patient: a case report and review of the literature. Infect. 2013;41:859-62.

4. Montoya J, Liesenfeld O. Toxoplasmosis. Lancet. 2004;363:1965-76.

5. Howe DK, Sibley LD. Toxoplasma gondii comprises three clonal lineages: correlation of parasite genotype with human disease. J Infect Dis. 1995; 172:1561-6.

6. Ajzenberg D, Year H, Marty P, Paris L, et al. Genotype of 88 Toxoplasma gondii isolates associated with toxoplasmosis in immunocompromised patients and correlation with clinical findings. J Infect Dis. 2009;199:1155-67.

7. Su C, Zhang X, Dubey J. Genotyping of Toxoplasma gondii by multilocus PCR-RFLP markers: a high resolution and simple method for identification of parasites. Inter J Parasitol. 2006;36:841-8.

8. Fazaeli A, Carter P, Darde M, Pennington T. Molecular typing of Toxoplasma gondii strains by GRA6 gene sequence analysis. Inter J Parasitol. 2006;30: 637-42.

9. Grigg ME, Ganatra J, Boothroyd JC, Margolis TP. Unusual abundance of atypical strains associated with human ocular toxoplasmosis. J Infect Dis. 2001;184:633-9.

10. Khan A, Su C, German M, Storch G, Clifford D, Sibley LD. Genotyping of Toxoplasma gondii strains from immunocompromised patients reveals high prevalence of type I strains. J Clin Microbiol. 2005;43:5881-7.

11. Su C, Shwab E, Zhou P, Zhu X, Dubey JP. Moving towards an integrated approach to molecular detection and identification of Toxoplasma gondii. Parasitol. 2010;137:1-11.

12. Khan A, Dubey J, Su C, Ajioka JW, Rosenthal BM, Sibley LD. Genetic analyses of atypical Toxoplasma gondii strains reveal a fourth clonal lineage in North America. Inter J Parasitol. 2011;41:645-55.

13. Rahimi MT, Daryani A, Sarvi S, et al. Cats and Toxoplasma gondii: a systematic review and meta-analysis in Iran. Onderst J Vet Res. 2015;82:1-10

14. Razmi GR. Prevalence of feline coccidia in Khorasan province of Iran. J Appl Anim Res. 2000;17:301-3.

15. Veronesi F, Santoro A, Milardi GL, Diaferia M, Morganti G, Ranucci D, Gabrielli S. Detection of Toxoplasma gondii in feces of privately owned cats using two PCR assays targeting the B1 gene and the 529-bp repetitive element. Parasitol Res. 2017:116:1063-9.

16. Salman D, Pumidonming W, Oohashi E, Igarashi M. Prevalence of Toxoplasma gondii and other intestinal parasites in cats in Tokachi subprefecture, Japan. J Vet Med Sci. 2018;80:960-7.

17. Schares G, Vrhovec MG, Pantchev N, Herrmann DC, Conraths FJ. Occurrence of Toxoplasma gondii and Hammondia hammondi oocysts in the feces of cats from Germany and other European countries. Vet Parasitol. 2008;152:34-45.

18. Berger-Schoch AE, Herrmann DC, Schares G, Müller N, Bernet D, Gottstein B, Frey CF. Prevalence and genotypes of Toxoplasma gondii in feline feces (oocysts) and meat from sheep, cattle and pigs in Switzerland. Vet Parasitol. 2011;177:290-7.

19. Jung BK, Lee SE, Lim H, et al. Toxoplasma gondii B1 gene detection in feces of stray cats around Seoul, Korea and genotype analysis of two laboratorypassaged isolates. Korean J Parasitol. 2015:53:259-63.

20. Dabritz HA, Miller MA, Atwill ER, Gardner IA, Leutenegger CM, Melli AC, Conrad PA. Detection of Toxoplasma gondii-like oocysts in cat feces and estimates of the environmental oocyst burden. J Am Vet Med Assoc. 2007; 231:1676-84.

21. Chemoh W, Sawangjaroen N, Nissapatorn V, Sermwittayawong N. Molecular investigation on the occurrence of Toxoplasma gondii oocysts in cat feces using TOX-element and ITS-1 region targets. Vet J. 2016;215:118-22.

22. Jokelainen $P$, Simola O, Rantanen E, Näreaho A, Lohi H, Sukura A. Feline toxoplasmosis in Finland: cross-sectional epidemiological study and case series study. J Vet Diagn Investig. 2012;24:1115-24.

23. Ding H, Gao YM, Deng Y, Lamberton PH, Lu DB. A systematic review and meta-analysis of the seroprevalence of Toxoplasma gondii in cats in mainland China. Parasit Vectors. 2017;10:27. https://doi.org/10.1186/s13071017-1970-6.

24. Dubey JP, Lindsay D, Speer C. Structures of Toxoplasma gondii tachyzoites, bradyzoites, and sporozoites and biology and development of tissue cysts. Clinic Microbiol Rev. 1998;11:267-99.

25. Hooshyar H, Rostamkhani P, Arbabi M. Study on growth of Toxoplasma gondii tissue cyst in laboratory mouse. Jundi J Microbiol. 2009;2:140-3.

26. Razmi GR, Ghezi K, Mahooti A, Naseri Z. A serological study and subsequent isolation of Toxoplasma gondii from aborted ovine fetuses in Mashhad area. Iran J Parasitol. 2010;96:812-4. 
27. Dubey JP, Su C, Cortés JA, Sundar N, Gomez-Marin JE, Polo L, Zambrano L, Mora LE, Lora F, Jimenez J, Kwok OC, Shen SK, Zhang X, Nieto A, Thulliez P. Prevalence of Toxoplasma gondii in cats from Colombia, South America and genetic characterization of T. gondii isolates. Vet Parasitol. 2006b;141:42-7.

28. Dubey JP, Su C, Oliveira J, Morales JA, Bolaños RV, Sundar N, Kwok OC, Shen SK. Biologic and genetic characteristics of Toxoplasma gondii isolates in free-range chickens from Costa Rica, Central America. Vet Parasitol. 2006a;139:29-36.

29. Chemoh W, Sawangjaroen N, Nissapatorn V, Sermwittayawong N. Molecular investigation on the occurrence of Toxoplasma gondii oocysts in cat feces using TOX-element and ITS-1 region targets. Vet Parasitol Vet Parasitol Reg Stud Reports. 2018;13:105-9.

30. Dubey JP, Sundar N, Gennari SM, Minervino AH, Farias NA, Ruas JL, dos Santos TR, Cavalcante GT, Kwok OC, Su C. Biologic and genetic comparison of Toxoplasma gondii isolates in free-range chickens from the northern Pará state and the southern state Rio Grande do Sul, Brazil revealed highly diverse and distinct Parasite populations. Vet Parasitol. 2007;143:182-8.

31. Zia-Ali N, Fazaeli A, Khoramizadeh M, Aizenberg D, Dardé M, KeshavarzValian H. Isolation and molecular characterization of Toxoplasma gondii strains from different hosts in Iran. Parasitol Res. 2007;101:111-5.

32. Tavalla M, Oormazdi H, Akhlaghi L, Shojaee S, Razmjou E, Hadighi R, Meamar A. Genotyping of Toxoplasma gondii isolates from soil samples in Tehran, Iran. Iran J Parasitol. 2013;8:227-33.

33. Khademvatan S, Saki J, Yousefi E, Abdizadeh R. Detection and genotyping of Toxoplasma gondii strains isolated from birds in the southwest of $\mathrm{Iran}$. $\mathrm{Br}$ Poult Sci. 2013;54:76-80.

34. Kareshk TA, Mahmoudvand H, Keyhani A, Oliaee TR, Mohammadi M, Babaei Z, Hajhosseini M, Zia-Ali N. Molecular detection and genetic diversity of Toxoplasma gondii in different tissues of sheep and goat in eastern Iran. Trop Biomed. 2017;34:681-90.

35. Shariat Bahadori E, Dalimi A, Namroodi S, Pirestan M. Phylogenetic analysis of Toxoplasma gondii type II and type III by PCR-RFLP plus sequencing on wild-rats of Golestan Forest, Iran. Vet Sci Technol. 2018;9:3. https://doi.org/ 10.4172/2157-7579.1000541.

36. Ajzenberg D, Dumètre A, Dardé ML. Multiplex PCR for typing strains of Toxoplasma gondii. J Clin Microbiol. 2005;43:1940-3.

37. Dubey JP, Gennari SM, Labruna MB, Camargo LM, Vianna MCB, Marcet PL, Lehmann T. Characterization of Toxoplasma gondii isolates in free-range chickens from Amazon, Brazil. J Parasitol. 2006;92:36-40.

38. Dubey JP, Moura L, Majumdar D, Sundar N, Velmurugan G, Kwok O, Kelly P, Krecek R, Su C. Isolation and characterization of viable Toxoplasma gondii isolates revealed possible high frequency of mixed infection in feral cats (Felis domesticus) from St Kitts, West Indies. Parasitology. 2009;136:589-94.

39. Chen Z, Gao J, Huo X, Wang L, Yu L, Halm-Lai F, Xu Y, Song W, Hide G, Shen J. Genotyping of Toxoplasma gondii isolates from cats in different geographic regions of China. Vet Parasitol. 2011;183:166-70.

40. Vilares A, Gargaté MJ, Ferreira I, Martins S, Júlio C, Waap H, Ângelo H, Gomes JP. Isolation and molecular characterization of Toxoplasma gondii isolated from pigeons and stray cats in Lisbon, Portugal. Vet Parasitol. 2014; 205:506-11.

41. Yekkour F, Aubert D, Mercier A, Murat JB, Khames M, Nguewa P, Ait-Oudhia K, Villena I, Bouchene Z. First genetic characterization of Toxoplasma gondii in stray cats from Algeria. Vet Parasitol. 2017;239:31-6.

42. Robert-Gangneux F, Dardé ML. Epidemiology of and diagnostic strategies for toxoplasmosis. Clin Microbiol Rev. 2012;25:264-96.

43. Burg JL, Grover CM, Pouletty P, Boothroyd JC. Direct and sensitive detection of a pathogenic protozoan, Toxoplasma gondii, by polymerase chain reaction. J Clin Microbiol. 1989;27:1787-92.

44. Petrie A, Watson P. Statistic for veterinary and animal science. Oxford: Blackwell Publishing; 2006.

\section{Publisher's Note}

Springer Nature remains neutral with regard to jurisdictional claims in published maps and institutional affiliations.

Ready to submit your research? Choose BMC and benefit from:

- fast, convenient online submission

- thorough peer review by experienced researchers in your field

- rapid publication on acceptance

- support for research data, including large and complex data types

- gold Open Access which fosters wider collaboration and increased citations

- maximum visibility for your research: over $100 \mathrm{M}$ website views per year

At BMC, research is always in progress.

Learn more biomedcentral.com/submissions 